\title{
Biological maturation and $\beta$-adrenergic effectors: development of $\beta$-adrenergic receptors in rabbit heart
}

\author{
William Schumacher*, Bernard L. Mirkin and J. R. Sheppard**
}

Division of Clinical Pharmacology, Departments of Pharmacology and Pediatrics, Medical School, De-

partment of Genetics and Cell Biology, Dight Institute for Human Genetics, University of Minnesota, Minneapolis, MN 55455, U.S.A.

\section{Summary}

The $\beta$-adrenergic receptor, transduction processes and catalytic activity of the adenylate cyclase enzyme complex have been investigated in rabbit heart at different stages of biological maturation. The binding of $\left[{ }^{3} \mathrm{H}\right]$-dihydroalprenolol to a washed membrane preparation isolated from rabbit ventricular muscle was used to characterize $\beta$-adrenergic receptors. Significant age-related differences were noted in $\beta$-receptor affinity $\left(K_{d}\right)$ and density (RD) of neonatal and adult animals; the adult $K_{d}$ was 3.7-fold greater and the RD 2-fold higher than the neonates. No significant differences in these parameters were detected among the 27 -day old fetus and the 1- and 7-day old neonates. Age-dependent differences in agonist isoproterenol affinity for the receptor were not observed in contrast to the significant changes in antagonist (DHA) affinity.

Age-related changes in receptor affinity were also quantitated by determining the inhibitory potency of alprenolol on isoproterenol stimulated adenylate cyclase enzyme activity. A decreased affinity of the $\beta$-adrenergic receptor for alprenolol in the adult heart was indicated by a 3.7-fold greater $\mathrm{K}_{\mathrm{i}}$ for the adult than the 1-day old neonate. Ontogenic variations in the coupling efficiency between the receptor and catalytic components of the adenylate cyclase complex were also evaluated. The $\mathrm{K}_{\mathrm{d}}$ of the $\beta$-adrenergic receptor for isoproterenol and the EC50 for adenylate cyclase stimulation were determined under similar conditions. The corresponding coupling index $\left(\mathrm{K}_{\mathrm{d}} / \mathrm{EC} 50\right)$ was found to be 2.4-fold greater in the 1-day old neonate than adult, suggesting that for a given percentage increase in adenylate cyclase activity, a lower percentage of $\beta$-adrenergic receptor sites need be occupied in the neonate. These data extend previous studies (29) and indicate all components of the rabbit heart adenylate cyclase enzyme complex (i.e., the $\beta$-adrenergic receptor, the GTP-dependent transduction event, and the catalytic subunit) exhibit significant developmental changes.

\section{Introduction}

The major functional components of the adenylate cyclase $(\mathrm{AC})$ enzyme complex consist of a receptor that selectively recognizes and binds specific hormones, a catalytic subunit that promotes formation of adenosine 3':5'-monophosphate (cAMP) from ATP and a transducer or coupling system that determines the efficiency with which an occupied receptor stimulates or inhibits the catalytic activity (26). Numerous studies have described the effects of biological maturation on AC alone (15); however, few have examined the functional integration of the components during development (29).

In the present investigation, several $\beta$-adrenergic receptor-related parameters (i.e., receptor-ligand

\footnotetext{
* Current address: William A. Schumacher, Ph.D., Department of Pharmacology, University of Michigan, M 6322 Medical Science Building, Ann Arbor, MI 48109, U.S.A.
}

** Reprint address: J. R. Sheppard, Dight Institute for Human Genetics, 400 Church Street S. E., Minneapolis, MN 55455, U.S.A. 
binding, coupling efficiency and AC activity) have been concurrently evaluated in the 27-day old fetal, 1 - and 7-day old neonatal and adult rabbit hearts. These data suggest that changes in $\beta$-adrenergic receptor affinity and density as well as coupling efficiency occur in the rabbit heart during the postnatal period.

\section{Methods}

\section{Washed particulate membrane (WPM) preparations}

New Zealand White Rabbits were obtained from the Oak Crest Rabbitry in Hanover, Minnesota. Average weights (mean \pm S.D.) were: $35 \pm 12 \mathrm{~g}$ (27-day old fetus), $59 \pm 13 \mathrm{~g}$ (1-day old), $113 \pm 29 \mathrm{~g}$ (7-day old), and $2.8 \pm 0.4 \mathrm{~kg}$ (adult). Animals were sacrificed by a stunning blow to the head, the hearts excised within 2-3 minutes and placed in ice-cold buffer $A\left(10 \mathrm{mM}\right.$ Tris- $\mathrm{HCl}, \mathrm{pH} 7.4$ at $4{ }^{\circ} \mathrm{C}$ with $2 \mathrm{mM}$ dithiothreitol). The number of hearts prepared simultaneously varied according to the age of the animal. In general, the ensuing schedule was used: 27-day old fetus (9-10 hearts), 1- and 7-day old neonate (4-5 hearts) and adult ( 1 heart). The pooled hearts were always obtained from littermates. Atria and vessels were removed and the resulting ventricular muscle minced with a scissors. All tissue preparation was carried out at $4^{\circ} \mathrm{C}$.

The ventricular tissue yields were approximately 1.0 gram (27-day old fetus), 1.0-1.5 grams (1-day old), 1.5-2.0 grams (7-day old), and 2-4 grams (adult). The tissue mince was suspended in buffer $A$ (10 volumes/wt) and homogenized at $4{ }^{\circ} \mathrm{C}$ in a Waring blender for 6-16 seconds duration, depending upon the amount of cardiac tissue used. Further homogenization was carried out in a Tekmar SDT tissuemizer using a 10 -sec duration at setting 70 and a $2-\mathrm{sec}$ duration at setting 100 . The tissue suspension was then filtered through a $250 \mu$ nylon mesh and the filtrate collected.

Washed particulate membranes (WPM) were prepared by subjecting this filtrate to the following series of low speed centrifugations using a Sorvall SS-34: $600 \mathrm{~g}$ for $15 \mathrm{~min}, 400 \mathrm{~g}$ for $10 \mathrm{~min}, 200 \mathrm{~g}$ for $10 \mathrm{~min}$, and $200 \mathrm{~g}$ for $10 \mathrm{~min}$. The pellet was retained after each centrifugation and resuspended in 5 volumes of buffer $A$ with 6 strokes of a motor- driven Teflon pestle homogenizer. The pellet from the $600 \mathrm{~g}$ centrifugation was gently washed with buffer $A$ to remove the fluffy lipid layer which was discarded. Following the final $200 \mathrm{~g}$ centrifugation the pellet was resuspended in 10 volumes of buffer $B$ (buffer $A+0.25 \mathrm{M}$ sucrose) and centrifuged at $30000 \mathrm{~g}$ for $15 \mathrm{~min}$. The resulting pellet was washed three times with $5 \mathrm{ml}$ of buffer $C(5 \mathrm{~m} \mathrm{M} \mathrm{MgCl}$ and $50 \mathrm{mM}$ Tris- $\mathrm{HCl} \mathrm{pH} \mathrm{7.4,} \mathrm{at} 37^{\circ} \mathrm{C}$ ) and resuspended with a motor-driven teflon pestle homogenizer in an equal volume of buffer $C$ to yield approximately $2 \mathrm{mg}$ protein $/ \mathrm{ml}$. This suspension was aliquoted into $0.5-2.0 \mathrm{ml}$ volumes, frozen immediately in dry ice-acetone and stored at $-70^{\circ} \mathrm{C}$. Membranes could be stored in this manner for up to 9 months without loss of receptor binding or adenylate cyclase activity; however, they were typically used within 3 months. This preparation was similar to that described by Snyder and Drummond (31), the major alteration being the elimination of the $\mathrm{KCl}$ extraction of contractile proteins. Proteins were determined by the Lowry method (19) using a standard comprised of bovine serum albumin.

\section{Adenylate cyclase assay}

The enzymatic reaction was carried out in an incubation volume of $0.5 \mathrm{ml}$ that contained $50 \mathrm{mM}$ Tris- $\mathrm{HCl}$ ( $\mathrm{pH} 7.4$ ), $1.8 \mathrm{mM}$ ATP, $2.5 \mu \mathrm{g} \mathrm{R020}$ (phosphodiesterase inhibitor), $0.25 \mathrm{mM}$ EGTA, $2 \mathrm{mM}$ mercaptoethanol, 1.9 units pyruvate kinase (PK), $5 \mathrm{mM}$ phosphoenolpyruvate (PEP), $5.5 \mathrm{mM}$ $\mathrm{KCl}, \quad 1.0 \mu \mathrm{M}$ guanyl-5'-yl imidodiphosphate (Gpp(NH)p, a GTP analog), $2.5 \mathrm{mM} \mathrm{MgCl}_{2}$ and approximately $0.1 \mathrm{mg}$ membrane protein. Reactions were initiated by addition of membrane suspensions to prewarmed tubes that were maintained in an oscillating water bath set at $37^{\circ} \mathrm{C}$. Incubations were carried out for 8 -min periods during which time enzyme velocities were shown to be linear. All reactions were terminated by inserting the test tube in a boiling water bath for $3 \mathrm{~min}$. Samples were stored at $4{ }^{\circ} \mathrm{C}$ until assayed for cAMP by a competition binding procedure $(4,29)$.

\section{$\beta$-Adrenergic receptor binding assay}

The ligand binding reaction was performed at $37^{\circ} \mathrm{C}$ in an oscillating water bath. All reactions were carried out in triplicate. This process was in- 
itiated by adding $0.08 \mathrm{ml}$ of membrane preparation $(0.1-0.3 \mathrm{mg}$ protein) to a reaction mixture $(0.2 \mathrm{ml}$ final volume) contained in polystyrene tubes. The incubation media were similar to those used in the adenylate cyclase enzyme assay and included: $50 \mathrm{mM}$ Tris- $\mathrm{HCl}$ (pH 7.4), $1.8 \mathrm{mM} \mathrm{ATP,} 2.5 \mu \mathrm{g}$ R020, $2.5 \mathrm{mM}$ EGTA, $2 \mathrm{mM}$ mercaptoethanol, $5 \mathrm{mM}$ PEP, 1.9 units $\mathrm{PK}, 5.5 \mathrm{mM} \mathrm{KCl}, 1 \mathrm{mM}$ $\mathrm{MgCl}_{2}$ and $\left[{ }^{3} \mathrm{H}\right]-\mathrm{DHA}$. Non-specific binding was determined by addition of $10 \mu \mathrm{M}$ propranolol to duplicate tubes. The reaction was terminated after $13 \mathrm{~min}$ by rapid addition of $3 \mathrm{ml}$ ice-cold buffer $C$. The entire mixture was then filtered over a Gelman type AE glass fiber filter paper held in a millipore filtration manifold and washed with $12 \mathrm{ml}$ of cold buffer $C$. A continuous vacuum sufficient to produce a flow rate of $1 \mathrm{ml} / \mathrm{sec}$ was applied during the entire filtration which was completed within $20 \mathrm{sec}$. The filters were air dried and placed in a vial containing $10 \mathrm{ml}$ of scintillation cocktail (toluene with $0.04 \% 2 \mathrm{a} 70$ omniflour). Samples were counted in a scintillation spectrometer at an efficiency of $45 \%$ for $10 \mathrm{~min}$.

\section{Statistical analysis}

Tests of equality between the means of groups were performed using the Student's $t$-test. When more than two groups were compared, interactions were determined by the one factor analysis of variance (ANOVA) or two factor ANOVA with repeated measures; if interactions were found, Duncan's least square test was used to determine which group means differed significantly. Least squares linear regression analysis was employed in Scatchard and Schild plot analyses.

\section{Materials}

$\left[{ }^{3} \mathrm{H}\right]$-cyclic AMP (40-60 Ci/mmole) and $\left[{ }^{3} \mathrm{H}\right]$ DHA (32-49 Ci/nmole) were purchased from the New England Nuclear Co. and (d-, 1-) Gpp(NH)p from ICN Pharmaceuticals. 2-Mercaptoethanol was obtained from Eastman Organic, $2 a 70$ from Research Products International and Norit SG Extra charcoal from the Baker Company. ATP, phosphoenolpyruvate, pyruvate kinase, DT , BSA, d, 1and 1-isoproterenol, 1-phenylephrine and $d-$ and l-norepinephrine were purchased from Sigma. Propranolol and l-alprenolol were generously pro- vided by the Ayerst Pharmaceutical Co. and RO20-1724 was a gift from H. Sheppard (HoffmanLaRoche).

\section{Results}

$\left[{ }^{3} \mathrm{H}\right]-\mathrm{DHA}$ binding to washed particulate membranes (WPM): characteristics of the ligand-receptor interaction

The binding properties of $\left[{ }^{3} \mathrm{H}\right]-\mathrm{DHA}$ to WPM was initially studied in preparations derived from adult rabbit hearts. The specific binding of $\left[{ }^{3} \mathrm{H}\right]$ DHA to receptor sites was saturated with increasing ligand concentration and Scatchard analyses of these data (Fig. 1) demonstrated a $\mathrm{K}_{\mathrm{d}}$ of $11.3 \mathrm{nM}$ and a RD of $176 \mathrm{fmol} / \mathrm{mg}$ protein. Specific binding at $10 \mathrm{nM}\left[{ }^{3} \mathrm{H}\right]$-DHA was $70 \%$ of the total counts bound. About half of the non-specific binding was present on the filter discs.

Stereospecificity of the ligand-receptor interaction was determined by comparing the displacement of bound $\left[{ }^{3} \mathrm{H}\right]-\mathrm{DHA}$ in the presence and absence of $\mathrm{l}$ - and $\mathrm{d}$-isomers of several $\beta$-adrenergic agonists (Fig. 2). The compounds employed in these experiments exhibited a high order of selec-

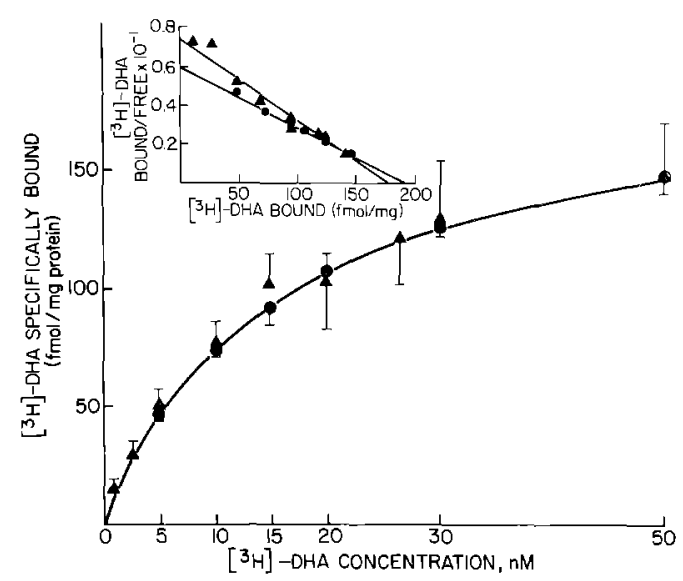

Fig. I. Specific binding of $\left[{ }^{3} \mathrm{H}\right]-\mathrm{DHA}$ to myocardial membranes (WPM) from adult rabbits. WPM $(\bullet, \bullet)$ fractions were incubated as described in Methods. Specific binding, that displaceable by $10^{-5} \mathrm{M}$ dl-propranolol has been plotted as a function of $\left[{ }^{3} \mathrm{H}\right]-\mathrm{DHA}$ concentration. The insert is a Scatchard plot (27) of the data from which the $K_{d}$ and $R D$ were estimated from the slopes and abscissa intercepts, respectively. Results were averaged from 2 experiments on separate membrane preparations. Data expressed as mean $\pm \mathrm{SEM}$. 


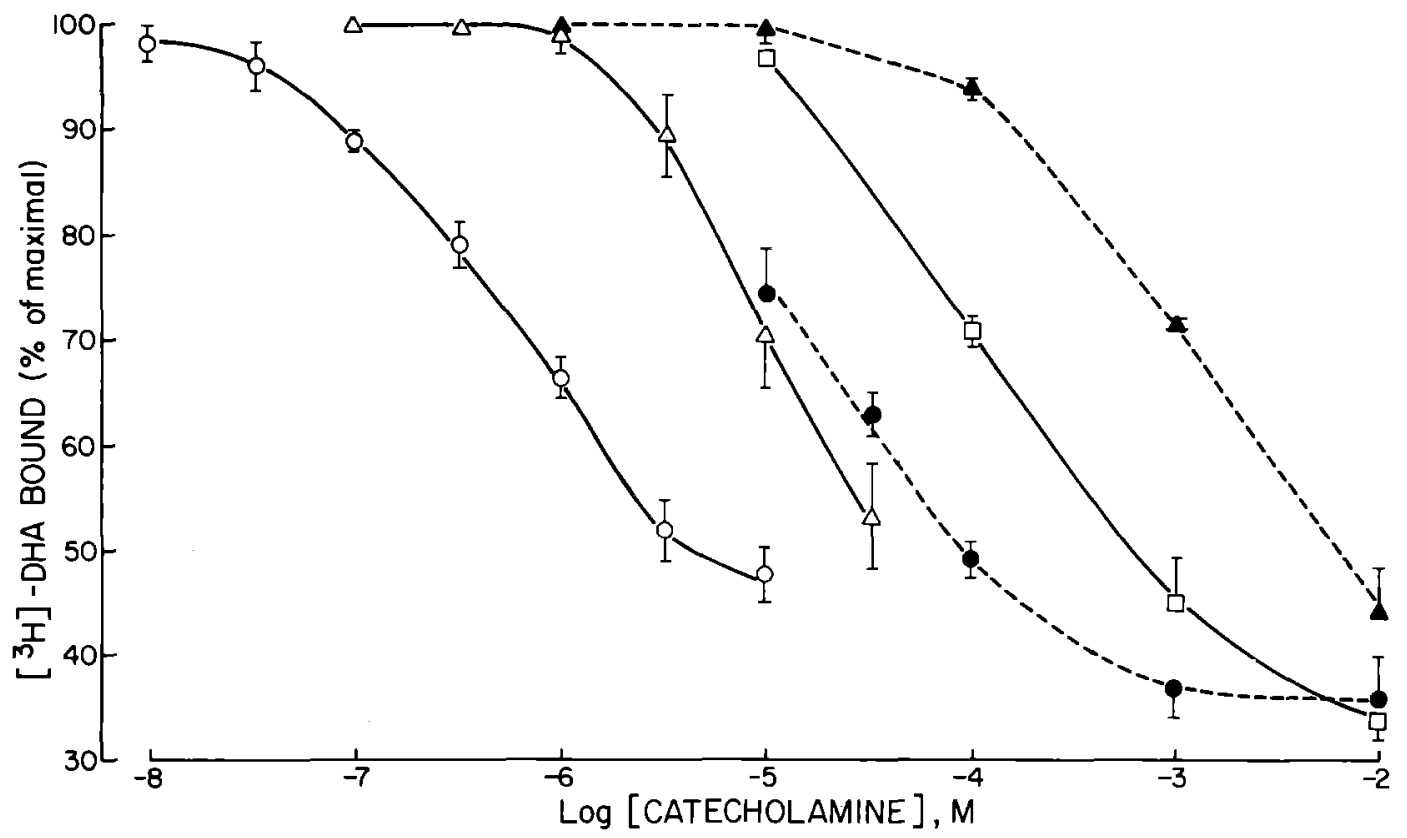

Fig. 2. Effect of $\beta$-adrenergic agonists on [ $\left.{ }^{3} \mathrm{H}\right]$-DHA binding in adult rabbit myocardial membranes. WPM from three adult rabbits were incubated as described in Methods with $10 \mathrm{nM}\left[{ }^{3} \mathrm{H}\right]$-DHA and various concentrations of the following $\beta$-adrenergic agonists: l-isoproterenol $(O)$, d-isoproterenol $(\bullet)$, l-norepinephrine $(\Delta)$, d-norepinephrine ( $\bullet)$, l-phenylephrine ( $\square$ ). Binding was expressed as the percentage of total $\left[{ }^{3} \mathrm{H}\right]-\mathrm{DHA}$ bound and was plotted against agonist concentration. Specific binding averaged $75 \%$ of the total counts bound. Data expressed as mean $\pm \mathrm{SEM}(n=3) . \mathrm{K}_{\mathrm{d}}$ values were calculated from these data using the equation $\mathrm{K}_{\mathrm{d}}=\mathrm{IC}_{50} / \mathrm{l}+(\mathrm{S}) / \mathrm{K}_{\mathrm{m}}$ where $\mathrm{IC}_{50}$ represents the concentration of drug inhibiting specific binding by $50 \%$, S equals the concentration of [ $\left.{ }^{3} \mathrm{H}\right]-\mathrm{DHA}$ and $\mathrm{K}_{\mathrm{m}}$ the $\mathrm{K}_{\mathrm{d}}$ of $\left[{ }^{3} \mathrm{H}\right]$-DHA determined from Seatchard analysis. The resulting $\mathrm{K}_{\mathrm{d}}(\mu \mathrm{M})$ values were: 0.3 (l-isoproterenol), 8.5 (d-isoproterenol), 4.9 (l-norepinephrine), 550 (d-norepinephrine), 55 (l-phenylephrine).

tively and the following order of potency: l-isoproterenol $>$ l-norepinephrine $>$ l-phenylephrine. The relative potency of the $\mathrm{l}$ - and $\mathrm{d}$-stereoisomers $1 / \mathrm{d}$ in this regard was 11 for norepinephrine, and 28 for isoproterenol.

Kinetic analyses of specific $\left[{ }^{3} \mathrm{H}\right]-\mathrm{DHA}$ binding to WPM demonstrated that equilibrium was achieved within $2 \mathrm{~min}$ and remained stable for $15 \mathrm{~min}$. When $10 \mu \mathrm{M} \mathrm{d}$-, 1-propranolol was added to the reaction mixture, after equilibrium had been established, about $90 \%$ of the specifically bound $\left[{ }^{3} \mathrm{H}\right]-\mathrm{DHA}$ was dissociated within $3 \mathrm{~min}$ (data not shown).

Effect of biological maturation on binding of $\left[{ }^{3} H\right]$ DHA to washed particulate membranes

The relationship between $\left[{ }^{3} \mathrm{H}\right]-\mathrm{DHA}$ concentration and specific binding of WPM derived from 27-day old fetal, 1- and 7-day old neonatal and adult rabbits was analyzed (Fig. 3). Specific binding in these experiments was approximately $70 \%$ of the total binding at $10 \mathrm{nM}\left[{ }^{3} \mathrm{H}\right]-\mathrm{DHA}$. Saturation was more clearly observable in WPM isolated from the 27-day old fetus and adult than in the 1- or 7-day old neonate over a broad concentration is ligand used (1-50 nM, [ $\left.\left.{ }^{3} \mathrm{H}\right]-\mathrm{DHA}\right)$. Scatchard analyses (27) of these data were linear for the adult and 27-day old fetus, suggesting that a single class of binding sites dominated in these preparations. In contrast, the 1- and 7-day old neonates generated curvilinear plots, reflecting a lack of saturation between $30-50$ nM $\left[{ }^{3} \mathrm{H}\right]-\mathrm{DHA}$ (Fig. 4).

The $K_{d}$ and $R D$ values obtained for the high affinity binding sites are summarized in Table 1. There were no significant differences between the 27-day old fetus and 1-or 7-day old neonate with respect to either parameter. However, the adult $K_{d}$ was 3- to 4-fold greater and the RD approximately 2 -fold higher than any of the younger age groups. 


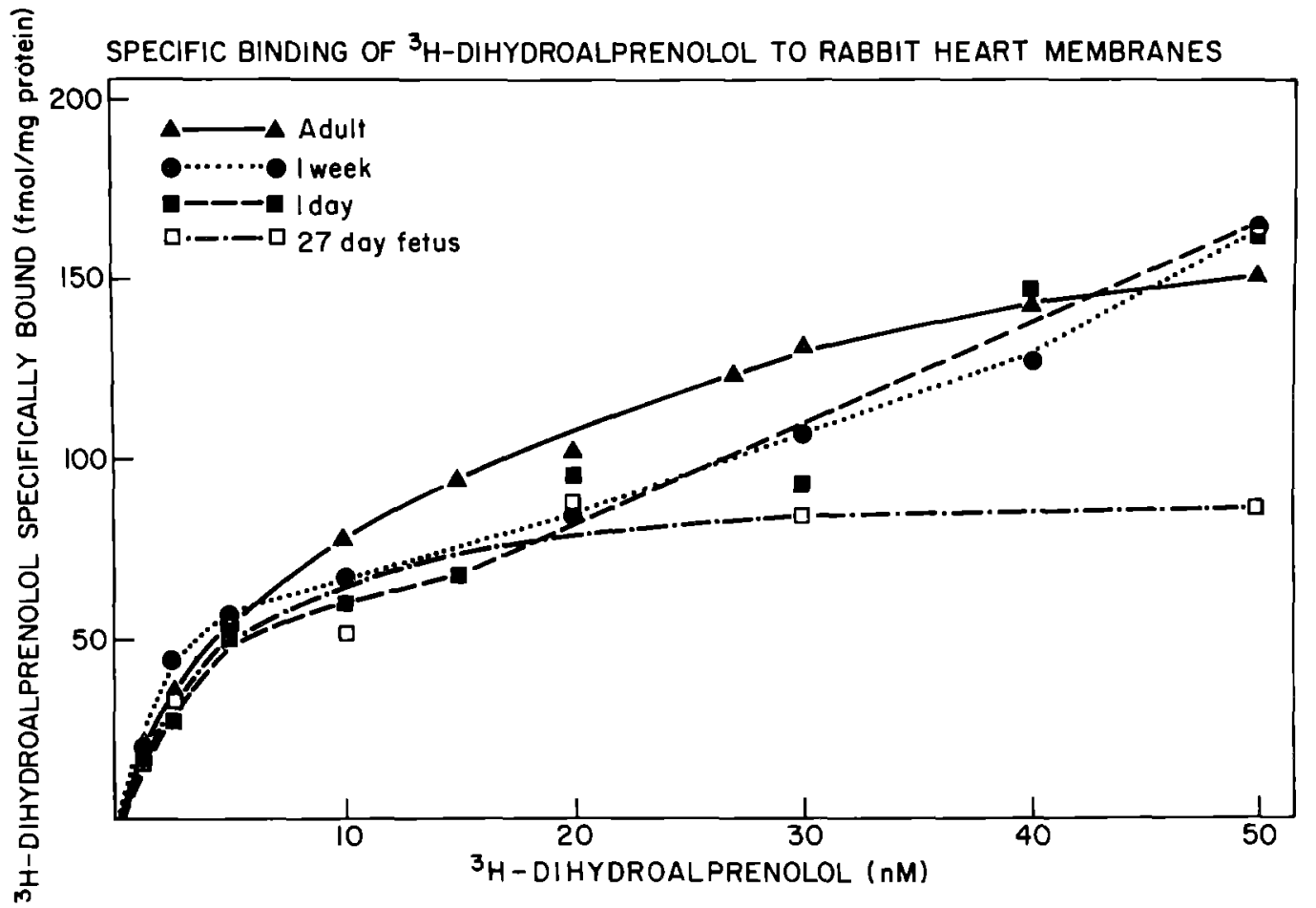

Fig. 3. Specific binding of $\left[{ }^{3} \mathrm{H}\right]-\mathrm{DH}$ A to rabbit myocardial membranes as a function of biological maturation. WPM from $27-$ day old fetus ( $\square$ ), 1-day old neonatal ( $\bullet$, 1-week old neonatal (O), and adult ( 4 ) were incubated with various concentrations of [ ${ }^{3} \mathrm{H}$ ]-DHA and specific binding determined as described in the Methods section. Each point constitutes an average of experiments performed on separate membrane preparations: 27 -day old fetus $(n=4-6)$, I-day old neonatal $(n=5)$, 1-week old neonatal $(n=4-10)$ and adult $(n=$ $4-8)$.
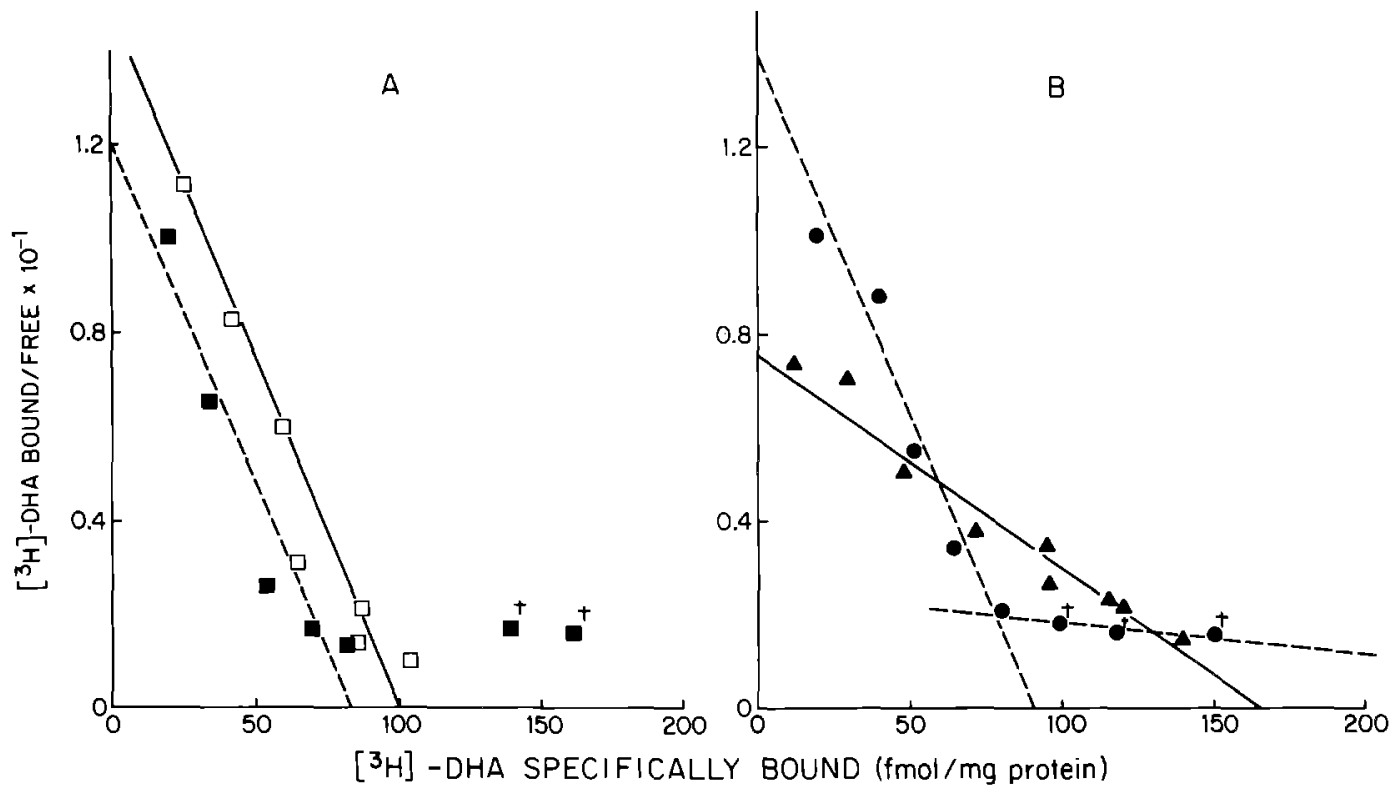

Fig. 4. Scatchard analysis of $\left[{ }^{3} \mathrm{H}\right]$-DHA specific binding to myocardial membranes as a function of biological maturation. Data analyzed were obtained from the experiments described in Fig. 3 and contrast the 27-day old fetus ( $\square$ ) and 1-day old neonatal ( () in panel A and the 7-day old neonatal $(O)$ with adult $(\Delta)$ in panel $B$. The correlation value $(r)$ for the least square regression analysis were as follows: $(\square)=$ $0.986,(\bullet)=0.940,(\bullet)=0.980,(\Delta)=0.920$. The $(+)$ data for the 1 - and 7 -day old neonatals were omitted from the analysis since they appeared to comprise another binding component of low affinity. 
Table 1. Scatchard analysis of individual membrane preparations.

\begin{tabular}{|c|c|c|c|}
\hline & $r$ & $K_{d}(n M)$ & $\mathrm{B}_{\max }(\mathrm{fmol} / \mathrm{mg})$ \\
\hline \multirow{9}{*}{ Adult } & -0.958 & 8.69 & 188 \\
\hline & -0.849 & 9,57 & 143 \\
\hline & -0.964 & 9.75 & 137 \\
\hline & -0.916 & 23.20 & 227 \\
\hline & -0.972 & 22.69 & 276 \\
\hline & -0.966 & 15.10 & 218 \\
\hline & -0.989 & 8.95 & 160 \\
\hline & -0.979 & 7.75 & 137 \\
\hline & Ave $\pm \mathrm{SEM}$ & $13.2 \pm 2.3$ & $186 \pm 18.0$ \\
\hline \multirow{7}{*}{$\begin{array}{l}\text { 7-day old } \\
\text { neonatal }\end{array}$} & -0.931 & 5.70 & 154 \\
\hline & -0.923 & 4.69 & 152 \\
\hline & -0.933 & 4.02 & 96 \\
\hline & -0.855 & 2.61 & 115 \\
\hline & -0.824 & 2.60 & 68 \\
\hline & -0.940 & 2.63 & 77 \\
\hline & Ave $\pm \mathrm{SEM}$ & ${ }^{\mathrm{a}} 3.8 \pm 0.5$ & ${ }^{\mathrm{a}} 111 \pm 12.7$ \\
\hline \multirow{6}{*}{$\begin{array}{l}\text { 1-day old } \\
\text { neonatal }\end{array}$} & 0.850 & 2.85 & 88 \\
\hline & 0.826 & 5.34 & 68 \\
\hline & 0.827 & 2.68 & 50 \\
\hline & 0.866 & 3.41 & 99 \\
\hline & 0.945 & 4.30 & 124 \\
\hline & Ave $\pm S E M$ & ${ }^{\mathrm{a}} 3.7 \pm 0.5$ & ${ }^{a} 86 \pm 13$ \\
\hline \multirow{7}{*}{$\begin{array}{l}27-\text { day old } \\
\text { fetus }\end{array}$} & 0.976 & 2.24 & 74 \\
\hline & 0.841 & 4.70 & 131 \\
\hline & 0.921 & 2.54 & 70 \\
\hline & 0.940 & 2.17 & 80 \\
\hline & 0.915 & 3.84 & 104 \\
\hline & 0.924 & 3.44 & 122 \\
\hline & Ave \pm SEM & & ${ }^{\mathrm{a}} 3.2 \pm 0.4$ \\
\hline
\end{tabular}

${ }^{a}$ Less than adult, $p<0.001$.

Data were obtained by the method indicated in Fig. 4 except that individual rather than pooled data have been presented.

Inhibition of WPM adenylate cyclase activity by l-alprenolol

The $K_{1}$ of l-alprenolol was determined by determining its potency as an inhibitor of isoproterenolstimulated adenylate cyclase activity in WPM prepared from adult and 1-day old rabbits. Increasing concentrations of l-alprenolol produced parallel shifts in the l-isoproterenol dose-response curve (data not shown). The competitive nature of this inhibition was confirmed by slope values of unity (range 0.991 to 1.074 ) and the ability of high iso- proterenol concentrations to overcome alprenolol inhibition. Schild analyses (28) of these data indicated that the average $K_{\mathrm{i}}$ for the adult $(3.50 \pm$ $0.17 \mathrm{nM}$ ) was 3.7 -fold greater $(p<0.05)$ than of the 1-day old neonate (1.01 $\pm 0.22 \mathrm{nM}$ ) (Fig. 5). These observations suggest that the affinity of the receptors in the neonatal WPM have a greater affinity for $\beta$-adrenergic antagonists than the adult.

Relationship between receptor occupation and adenylate cyclase activation by l-isoproterenol: coupling efficiency of reaction

The $\mathrm{IC}_{50}$ of isoproterenol for $\left[{ }^{3} \mathrm{H}\right]-\mathrm{DHA}$ occupied receptor sites was used to determine the $\mathrm{K}_{\mathrm{d}}$ of the agonist in WPM prepared from 1-day old and adult hearts. The average $K_{d}$ of the neonate $(0.32$ $\mu \mathrm{M})$ did not differ significantly from that of the adult $(0.30 \mu \mathrm{M})$. The average $\mathrm{EC}_{50}$ for isoproterenol-induced stimulation of adenylate cyclase was $0.047 \mu \mathrm{M}$ in the 1 -day old and $0.108 \mu \mathrm{M}$ in the adult $(p<0.001)$. In these experiments the GTP analog, $\mathrm{Gpp}(\mathrm{NH}) \mathrm{p}$, was always present in these experiments at a concentration of $1.0 \mu \mathrm{M}$. It failed to elicit any shift in the $\mathrm{EC}_{50}$ of isoproterenol, although the enzymatic activity of the preparation was increased two-fold in the presence of this compound. The coupling efficiency index $\left(\mathrm{K}_{\mathrm{d}} / \mathrm{EC}_{50}\right)$ determined from these data was found to be greater in the 1-day old neonate $(0.34 \mu \mathrm{M} / 0.047 \mu \mathrm{M}=\underline{6.8})$ than in adult $(0.30 \mu \mathrm{M} / 0.108 \mu \mathrm{M}=\underline{2.8})$.

\section{Discussion}

The binding of $\left[{ }^{3} \mathrm{H}\right]-\mathrm{DHA}$ to membrane fractions prepared from rabbit heart membranes has been shown to fulfill accepted criteria for the identification and characterization of $\beta$-adrenergic receptors. The lack of a well-defined saturation pattern for $\left[{ }^{3} \mathrm{H}\right]$-DHA specific binding was noted in WPM prepared from 1- and 7-day old neonatal myocardium. The resulting concave-upward Scatchard plot may indicate the existence of two classes of binding sites, a two step reaction process, or negative cooperativity among sites. Quantitation and interpretation of the $\mathrm{K}_{\mathrm{d}}$ was, therefore, made less precise by the non-linearity of these plots. Precedents for these observations have been previously published. Krawietz et al. (17) described a similar 


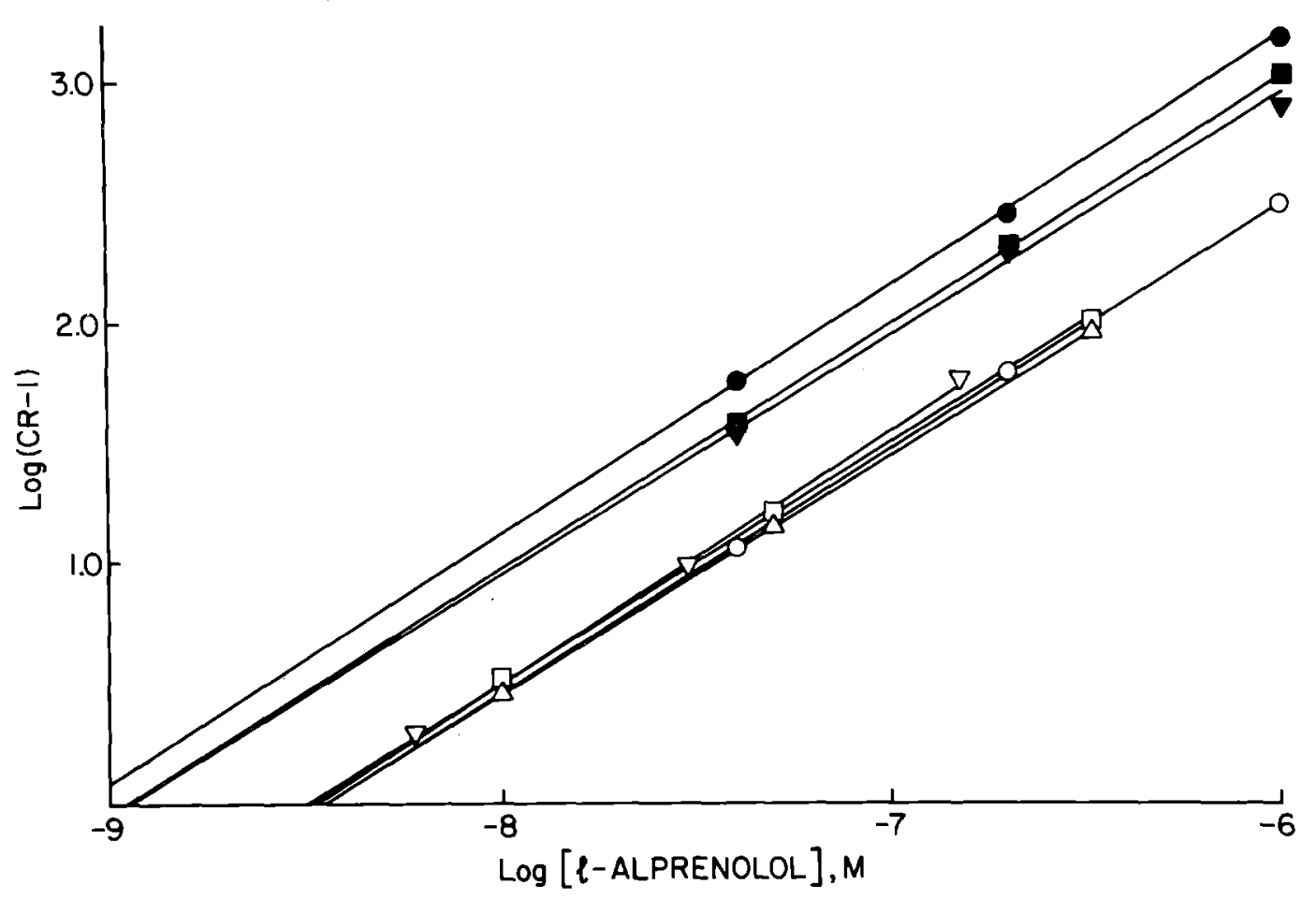

Fig. 5. Schild analysis of l-alprenolol inhibition of l-isoproterenol stimulated myocardial adenylate cyclase. Data were obtained from the experiments using 1 -day old neonatal $(\bullet, \boldsymbol{\bullet}, \bullet)$ or adult $(\Delta, O, \square, \nabla)$ preparations. Concentration ratios $(C R)$ were calculated by dividing the ratio of the EC50 for l-isoproterenol determined in the presence of alprenolol by EC50 determined in its absence. Log (CR-1) was plotted against alprenolol concentration. The abscissa intercepts were used to estimate the individual $\mathrm{K}_{\mathrm{i}}$ values. The individual $\mathrm{K}_{\mathrm{i}}(\mathrm{nm})$ values were: (v) $1.19,(\bullet) 1.07,(\bullet) 0.76,(\nabla) 1.074,(O) 3.65,(\Delta) 3.61,(\square) 3.28$.

curvilinear Scatchard analysis for $\left[{ }^{3} \mathrm{H}\right]$-DHA binding to guinea pig heart membranes and suggested this was due to negative cooperativity a mong receptors. Winek and Bhalla (34) reported that $\left[{ }^{3} \mathrm{H}\right]-\mathrm{D}-$ $\mathrm{HA}$ concentrations in excess of $5 \mathrm{nM}$, bound to a second class of low affinity sites in rat myocardium.

Due to the uncertainty of the $K_{d}$ values that could be estimated by this approach, we sought verification by determining the $\mathrm{K}_{\mathrm{i}}$ of adenylate cyclase with l-alprenolol. The null hypothesis for these studies was based on the assumption that the two forms of the antagonist (DHA and $\left[{ }^{3} \mathrm{H}\right]-\mathrm{DHA}$ ) lack intrinsic activity and possess equal affinity for the receptor as claimed by Mukherjee et al. (23); consequently, both parameters, $\mathrm{K}_{\mathrm{d}}$ and $\mathrm{K}_{\mathrm{i}}$, should be equal. These data revealed the $K_{d}$ 's to be about 3.5 -fold greater than the $K_{i}$ 's for WPM derived from either the 1-day old neonate or adult. Several lines of evidence favor the validity of the $\mathrm{K}_{\mathrm{i}}$ values. The $\mathrm{K}_{\mathrm{i}}$ obtained for the adult $(3.5 \mathrm{nM})$ was close to that reported by Kaumann and Birnbaumer (14) for the inhibition of myocardial adenylate cyclase activity $(4.2 \mathrm{nM})$ and papillary muscle contraction $(1.7 \mathrm{nM})$ by alprenolol. In addition, the Schild analysis conformed better to theoretical expectations than the Scatchard analysis.

Discrepancies between the $K_{d}$ and $K_{i}$ of an antagonist have been noted elsewhere in the literature. Coleman et al. (8) measured $K_{d}$ and $K_{i}$ values for various derivatives of phenoxypropranolamines in cardiac membranes. The relative $\mathrm{K}_{\mathrm{d}}$ values as estimated from linear regression analysis of these data were about 3-fold greater than the $\mathbf{K}_{\mathrm{i}}$ 's for cardiac membranes. Lucas et al. (20) found the $K_{d}$ for alprenolol and $\left[{ }^{3} \mathrm{H}\right]-\mathrm{DHA}$ to be two times greater than the $\mathrm{K}_{\mathrm{i}}$ in $\mathrm{C}_{6}$-glioma cells. Other investigators employing adult cardiac membrane preparations comparable to those used in this study have estimated $\mathrm{K}_{\mathrm{d}}$ 's for [ ${ }^{3} \mathrm{H}$ ]-DHA to range between 0.3 and $10.8 \mathrm{nM}$ (median $=6 \mathrm{nM}$ ) and RD's between $35-350 \mathrm{fmol} / \mathrm{mg}$ protein $($ median $=89 \mathrm{fmol} / \mathrm{mg}$ protein $(1,3,5,6,11,16,17,18,33,34)$. The only 
previous report on rabbit heart membranes (9) estimated a $\left[{ }^{3} \mathrm{H}\right]-\mathrm{DHA} \mathrm{K}_{\mathrm{d}}$ of $6.1 \mathrm{nM}$ as compared to $13.2 \mathrm{nM}$ in the present study.

We found that Schild and Scatchard analyses predicted a 3.7-fold increase in the $K_{d}$ of the adult receptor when compared to the neonate, indicating that Scatchard analysis accurately reflected changes in $\mathrm{K}_{\mathrm{d}}$ and RD occurring during development. In contrast to the differences in $K_{d}$ observed with alprenolol, the $K_{d}$ of isoproterenol determined in 1-day old and adult tissues were similar. These observations suggested the existence of developmentally regulated distinctions between agonist and antagonist binding to the $\beta$-adrenergic receptor. Other investigators using cardiac membrane preparations have indicated an absence of maturationally related changes in the $K_{d}$ of $\left[{ }^{3} \mathrm{H}\right]-D H A$. These studies employed rats $(3,32)$, and mice (5).

The demonstration of an increase in $\beta$-adrenergic receptor density in adult as compared to neonate cardiac membranes is also contrary to previous reports. Baker and Potter (3) and Whitsett and Darovec-Beckerman (32) observed a decrease in the $\mathrm{RD}$ (per $\mathrm{g}$ of tissue) of adult rats when compared to 2-week old animals. Chen et al. (5) described a progressive 4-fold increase in RD (relative to tissue weight) between the 17-day old fetus and 3-day old neonate, which was followed by a $50 \%$ reduction in $\mathrm{RD}$ at 3-5 months of age. While species-specific differences may account for the lack of correlation between these reports and the current study, variations in membrane preparation were also evident.

Changes in the reactivity of $\beta$-adrenergic effectors during development have been associated with numerous biological events including growth of sympathetic nerve fibers $(24,30)$, hormonal influences (12), as well as cellular proliferation and differentiation (7). Adrenergic innervation to the rabbit heart develops primarily during extrauterine life. Friedman et al. (10) reported that norepinephrine tissue levels reach adult values three weeks after parturition, with the major increase occurring between days 2 and 14. Roffi and Motelica-Heino (25) confirmed these data and noted a rapid increase in myocardial norepinephrine within 4 hours of birth, followed by little or no change between 4 and 72 hours. This was presumed to result from an enhancement of sympathetic activity following delivery. We were unable to detect any changes in receptor function or number during this phase of extrauterine development, which was marked by rapid increases in tissue catecholamine concentration. Our data suggest that variations in endogenous tissue norepinephrine levels may not be a significant modulator of RD during perinatal development. This contrasts with accompanying changes in $\mathrm{RD}$ observed following denervation supersensitivity (35) and agonist-induced desensitization (15).

It is well established that sympathetic induced myocardial responses are at least in part mediated by CAMP (22). Our results on the coupling efficiency of the AC system as estimated from the $\mathrm{K}_{\mathrm{d}} / \mathrm{EC}_{50}$ ratio for isoproterenol indicate that while fewer $\beta$-adrenergic receptors per mg protein are present in the neonate as compared to the adult, a smaller fraction need be occupied for maximal adenylate cyclase enzyme activation in the neonate.

The analysis of developmentally related changes in the adenylate cyclase enzyme complex is difficult and requires a broad perspective. This study has

Table 2. Characteristics of the $\beta$-adrenergic receptor, transduction and catalytic subunits of the 1-day old neonatal and adult rabbit heart adenylate cyclase complex

\begin{tabular}{|c|c|c|c|}
\hline \multirow[t]{2}{*}{ Subunit } & \multirow[t]{2}{*}{ Parameter } & \multicolumn{2}{|c|}{ Age of rabbit } \\
\hline & & 1-day old & adult \\
\hline \multirow[t]{3}{*}{ Receptor } & Receptor density (fmol/mg prot) & $86 \pm 13$ & $186 \pm 18$ \\
\hline & $\mathrm{K}_{\mathrm{d}}$ of $\mathbf{H}^{3}$-dihydroalprenolol (nM) & $3.7 \pm 0.5$ & $13.2 \pm 2.3$ \\
\hline & $\mathrm{K}_{\mathrm{d}}$ of 1-isoproterenol $(\mathrm{nM})$ & 340 & 300 \\
\hline \multirow[t]{3}{*}{ Transduction } & Coupling efficiency $\left(\mathrm{K}_{\mathrm{d} / \mathrm{EC}} \mathrm{C}_{50}\right.$ & & \\
\hline & for l-isoproterenol & 6.8 & 2.8 \\
\hline & $\mathrm{Gpp}(\mathrm{NH}) \mathrm{p}$ preincubation $(\mathrm{pmol} / \mathrm{min} / \mathrm{mg})$ & $25 \pm 1.8$ & $493 \pm 64$ \\
\hline \multirow[t]{3}{*}{ Catalytic } & Basal activity (pmol/min/nm) & $23 \pm 0.8$ & $18 \pm 0.3$ \\
\hline & $\mathrm{NaF}$ stimulated activity $(\mathrm{pmol} / \mathrm{min} / \mathrm{mg})$ & & \\
\hline & Activity after $5 \mathrm{hr}\left(4^{\circ} \mathrm{C}\right)$ & $221 \pm 28$ & $451 \pm 31$ \\
\hline
\end{tabular}


demonstrated that $\beta$-adrenergic receptor density (RD) in the heart increases approximately two-fold from birth to adult life. Receptor affinity for the $\beta$-adrenergic agonist, isoproterenol, does not appear to change; the coupling efficiency index of isoproterenol is greater in the neonate, potentially compensating for the decreased number of receptors present at this time (Table 2).

Sodium fluoride activation and $\mathrm{Gpp}(\mathrm{NH}) \mathrm{p}$ preincubation studies have also revealed a major increase in the catalytic capacity of adenylate cyclase with advancing age (29). In light of cyclic AMP's biological role as a second messenger, these alterations in the adenylate cyclase enzyme may be related to the other ontogenic changes which occur in cardiac muscle physiology.

\section{Acknowledgement}

This investigation was partially supported by funds from USPHS Grants GM-07466 and GM07397, the Hoffmann La Roche Foundation and the Leukemia Task Force.

\section{References}

I. Alexander, W. R., Williams, L. T. and Lefkowitz, R. J., 1975. Proc. Natl. Acad. Sci. U.S.A. 72: 1564-1568.

2. Aurback, G. P., Fedak, S. A., Woodward, C. J., Palmer, J. S., Hauser, D. and Troxler, F., 1974. Science 186: 1223-1224.

3. Baker, S. D. and Potter, L. T., 1980. Br. J. Pharmacol. 68: 65-70.

4. Brown, B. L., Albano, J. D. M., Ekins, R. P. and Sgherzi, A. M., 1971. Biochem. J. 121: 561-562.

5. Chen, F. C. M., Yamamura, H. I. and Roeske, W. R., 1979. Eur. J. Pharmacol. 58: 255-264.

6. Ciaraldi, T. and Marinetti, G. V., 1977. Biochem. Biophys. Res. Commun. 74: 984-991.

7. Claycomb, W. C., 1976. J. Biol. Chem. 251: 6082-6089.

8. Coleman, A. J., Paterson, D. S. and Somerville, A. R., 1979. Biochem. Pharmacol. 128: 1011-1013.

9. Coleman, A. J. and Somerville, A. R., 1977. Br. J. Pharmacol. 59: 83-93.

10. Friedman, W. F., Pool, P. E., Jacobowitz, D., Seagren, S. C. and Braunwald, E., 1968. Circ. Res. 23: 25-32.
11. Glaubiger, G., Tsai, B. S and Lefkowitz, R. J., 1978. Nature 273: $240-242$.

12. Green, T. D., O’Dea, R, F. and Mirkin, B. L., 1979. Ann. Rev. Pharmacol. Toxicol. 19: 285-322.

13. Howlett, A. C., VanArsdale, P. M. and Gilman, A. G., 1978. Mol. Pharmacol. 14: 531-539.

14. Kaumann, A. J. and Birnbaumer, L., 1973. Acta Phys. Lat. Amer. 23: 619-620.

15. Krall, J. F., Connelly, M. and Tuck, M. L., 1980. J. Pharmacol. Exp. Ther. 214: 554-560.

16. Krawietz, W., Poppert, D., Erdmann, E., Glossmann, H., Struck, C. J. and Konrad, C., 1976. Naunyn Schmiedeberg Arch. Pharmacol. 295: 215-224.

17. Krawietz, W., Weinsteiger, M., Pruchniewski, M. and Erdmann, E., 1979. Biochem. Pharmacol. 28: 2999-3007.

18. Limas, C. and Limas, C. J., 1978. Biochem. Biophys. Res. Commun. 83: 710-714.

19. Lowry, O. H., Rosebrough, W. J. and Randall, R. J., 1951. J. Biol. Chem. 193: 265-289.

20. Lucas and Bockaert, J., 1977. Mol. Pharmacol. 13: 314-329. 314-329.

21. Maguire, M. E., Ross, E. M. and Gilman, A. G., 1977. Adv. Cyclic Nucleotide Res. 8: 1-74.

22. Mayer, S. E., 1972. J. Pharmacol. Exp. Ther. 181: 116-125.

23. Mukherjee, C., Caron, M. G. and Coverstone, M., 1975. J. Biol. Chem. 250: 4869-4876.

24. Pappano, A. J., 1977. Pharmacol. Rev, 29: 3-33.

25. Roffi, J. and Motelica-Heino, I., 1975. Experientia (Basel) 31: 194-195.

26. Ross, E. M. and Gilman, A. G., 1977. Proc. Natl. Acad. Sci. U.S.A. 74: 3715-3719.

27. Scatchard, G., 1949. Ann. N.Y. Acad. Sci. 51: 660-672.

28. Schild, H. O., 1947. J. Pharmacol. 2: 189-206.

29. Schumacher, W., Sheppard, J. R. and Mirkin, B. L., 1982. J. Pharmacol. Exp. Ther. 223: 587-593.

30. Slotkin, T. A., Smith, P. G., Lau, C. and Bareis, D. L., 1980. In: Biogenic Amines in Development (Parves, S. and Parves, H. eds.), Elsevier, North Holland, Amsterdam.

31. Snyder, F. F. and Drummond, G. I., 1978. Arch. Biochem. Biophys. 185: 116-125.

32. Whitsett, J. A. and Darovec-Beckerman, L., 1981. Ped. Res, 15: $1363-1369$.

33. Williams, L. T. and Lefkowitz, R. J., 1977. J. Biol. Chem. 252: 2787-2789.

34. Winek, R. and Bhalla, R., 1979. Biochem. Biophys. Res. Commun 91: 200-206.

35. Yamada, S., Yamamura, H. I. and Roeske, W. R., 1980. Mol. Pharmacol. 18: 185-192.

Received 1 February 1983. 